\title{
Proces łączenia materiałów do budowy pojazdów i nadwozi w przemyśle samochodowym
}

\section{Process of joining materials to build vehicles and motor-car bodies in the automotive industry}

\section{Streszczenie}

Przedstawiono spawanie ramy pojazdu ciężarowego. Omówiono naprężenia występujące w ramach pojazdów ciężarowych i wymagania dotyczące ich wytrzymałości. Przedstawiono materiały stosowane do budowy pojazdów i nadwozi. Zaprezentowano technologię spawania ram pojazdowych - stosowane urządzenia, metodę spawania, przygotowanie złączy spawanych oraz parametry spawania.

Słowa kluczowe: spawanie, konstrukcja spawana, plan spawania

\section{Wstęp}

Przemysł samochodowy jest gałęzią gospodarki, w której prace spawalnicze mają ogromny udział. Obecnie najczęściej do łączenia materiałów wykorzystuje się trzy metody [2]:

- spawanie łukowe drutem topliwym w osłonie gazów MIG/MAG,

- spawanie łukowe drutem nietopliwym w osłonie gazów TIG,

- spawanie łukiem krytym pod topnikiem SAW.

Metody te są używane do łączenia elementów nadwozi oraz podwozi; przykładowo są to:

- zabudowy samowyładowcze (wywrotki),

- zabudowy stałe (cysterny, kontenery),

- szkielety nadwozi samonośnych,

- kabiny,

- wysięgniki żurawi,

- ramy nośne.

Ostatni z wymienionych elementów zostanie poddany szczegółowej analizie w niniejszej publikacji [1].

\section{Abstract}

A welding process of a frame of a truck was presented. Stresses, which occur in the frames of trucks and the requirements of their resistance were described in the following paper. Moreover, the materials used to build vehicles and motor-car bodies were depicted. A technology of welding frames of vehicles - common equipment, a method of welding, preparation of welding joints and the parameters of welding were given.

Keywords: welding, welded construction, welding procedure

\section{Naprężenia i wytrzymałość konstrukcji}

Rama nośna jest najważniejszą częścia pojazdu ciężarowego, scalającą elementy podwozia i nadwozia z elementami układu jezdnego. Spawane połączenia znajdujące się w obrębie ramy samochodu ciężarowego poddawane są cyklicznie występującym obciążeniom, które mogą powodować ich uszkodzenia w postaci pęknięć zmęczeniowych. Dlatego jednym z ważniejszych parametrów, jakie powinny charakteryzować połączenie spawane znajdujące się w obrębie ramy pojazdu, jest jego odpowiednio wysoka wytrzymałość zmęczeniowa na działanie obciążeń zmiennych.

Podczas eksploatacji pojazdów ciężarowych w elementach ich ram oraz połączeniach tych elementów, poza zmiennymi siłami, mogą wystąpić znaczne naprężenia o charakterze statycznym. Naprężenia te mogą wynikać z trudnych warunków ruchu pojazdu ciężarowego. W przypadku naczepy samochodowej naprężenia rozciągające w podłużnicach ramy wynikają z tego, że siła pociągowa przyłożona jest w przedniej części

Dr hab. inż. Jacek Słania, prof. PCz - Politechnika Częstochowska, mgr inż. Łukasz Kuk - Brembo Oddział Częstochowa. 
naczepy. Główne źródło oporów ruchu zlokalizowane jest natomiast w miejscu, gdzie znajdują się koła jezdne naczepy ciężarowej, czyli w jej tylnej części. W przypadku burty załadowczej (często instalowanej w tylnej części samochodu ciężarowego o nadwoziu skrzyniowym) naprężenia wynikają z unoszenia ułożonego na niej ładunku lub też z podnoszenia burty. W przypadku unoszenia nieobciążonej ładunkiem burty załadowczej naprężenia mogą osiągać wartości poniżej $180 \mathrm{MPa}$. Producenci pojazdów ciężarowych zalecają spawanie ram wyprodukowanych pojazdów różnymi metodami, głównie nisko- oraz średniotlenowymi.

Miejsca, gdzie zlokalizowane są złącza spawane, stają się obszarami koncentracji naprężeń, czyli tzw. koncentratorami. Poza występowaniem znacznych jednostkowych impulsów sił, podczas eksploatacji ram samochodowych występują także siły o mniejszej wartości. Przykładowy przebieg wartości naprężeń, zarejestrowany na elementach ramy samochodu ciężarowego poruszającego się z prędkością $40 \mathrm{~km} / \mathrm{h}$ po jezdni wykonanej z kostki brukowej, zamieszczono na rysunku 1.

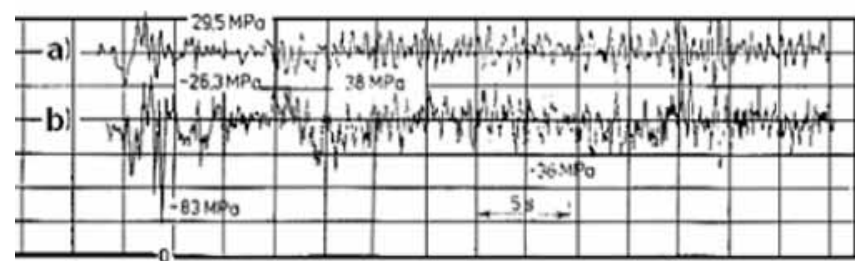

Rys. 1. Przebieg naprężeń zarejestrowany w elementach ramy samochodu ciężarowego poruszającego się z prędkością $40 \mathrm{~km} / \mathrm{h}$ po jezdni wykonanej z kostki brukowej [1]

Fig. 1. Process of stress recorded on the elements of a frame of a motor truck moving with a speed of $40 \mathrm{~km} / \mathrm{h}$ on the road made of Belgian blocks [1]

Równocześnie spawane połączenia znajdujące się w obrębie ramy samochodu ciężarowego poddawane są cyklicznie występującym naprężeniom, które mogą powodować ich uszkodzenia w postaci pęknięć zmęczeniowych. Dlatego jedną z ważniejszych cech, jaką powinno charakteryzować się połączenie spawane znajdujące się w obrębie ramy pojazdu, jest jego odpowiednio wysoka wytrzymałość zmęczeniowa.

W warunkach warsztatowych ważnymi metodami spawania są: spawanie elektryczne elektrodami zasadowymi oraz spawanie elektrodą topliwą w osłonie gazu aktywnego (MAG). Są one zalecane również jako metody napraw spawalniczych przez producentów pojazdów ciężarowych [2].

Materiały stosowane do budowy pojazdów i nadwozi

Obecnie w przemyśle samochodowym stosuje się stale niskostopowe o maksymalnej zawartości węgla do $0,22 \%$, stale ogólnego przeznaczenia, stale konstrukcyjne oraz stopy aluminium.

Wszystkie wyżej wymienione materiały muszą spełniać określone wymagania dotyczące:

- wytrzymałości na rozciąganie,

- sprężystości,

- udarności,
- twardości,

- plastyczności,

- ciągliwości

- spawalności,

- odporności na działanie wysokiej i niskiej temperatury,

- odporności na korozję chemiczną i atmosferyczną.

Do budowy ram podwozi samochodowych powszechnie stosuje się stal konstrukcyjną o oznaczeniu S355J2G3. W przypadku nadwozi samowyładowczych stosuje się stale Hardox lub Domex wytwarzane przez huty szwedzkiego koncernu SSAB.

Blachy ze stali Domex mają małą zawartość węgla i manganu. Stosuje się w ich przypadku walcowanie termomechaniczne z precyzyjnie kontrolowanymi sekwencjami podgrzewania, walcowania i chłodzenia. Blachy Domex mają granice plastyczności: $240,355,420,460,500$, 550, 600, 650, 700 MPa. Dostępne są również wersje Domex z oznaczeniem W (Water Resistant) o zwiększonej odporności na korozję atmosferyczną w gatunkach 350 , 550, 700, a także wersja Domex Wear o dużej odporności na ścieranie porównywalnej z dużo twardszymi blachami ulepszanymi cieplnie. Ta wersja stali jest wykorzystywana w elementach szczególnie narażonych na ścieranie przez twarde cząsteczki, np. kamień lub piasek [2].

Stale Hardox są wykorzystywane w zabudowach pracujących w szczególnie trudnych warunkach, np. wywrotki w kamieniołomach. Oprócz niezbędnej odporności na ścieranie jest tu konieczna duża odporność skrzyni ładunkowej na obciążenia udarowe (ważne przy załadunku dużych fragmentów skalnych). Wykorzystuje się stale Hardox 400, 450 i 500. Oznaczenia opisują twardość w skali Brinella, np. Hardox 400 ma twardość 370 $\div 430$ HB. Granice plastyczności wynoszą odpowiednio 1000, 1200 oraz $1300 \mathrm{MPa}$ [2].

\section{Prezentacja pojazdu na przykładzie naczepy ciężarowej}

Przystępując do omówienia technologii spawania, warto zacząć od zaprezentowania gotowego produktu, w postaci naczepy ciężarowej. Na rysunku 2 przedstawiono ramę nośną naczepy marki Sommer. Jest to pojazd po pracach spawalniczych, montażowych, lakierniczych oraz kontrolnych, przeznaczony do wykonania zabudowy u innego producenta (producenta nadwozi).

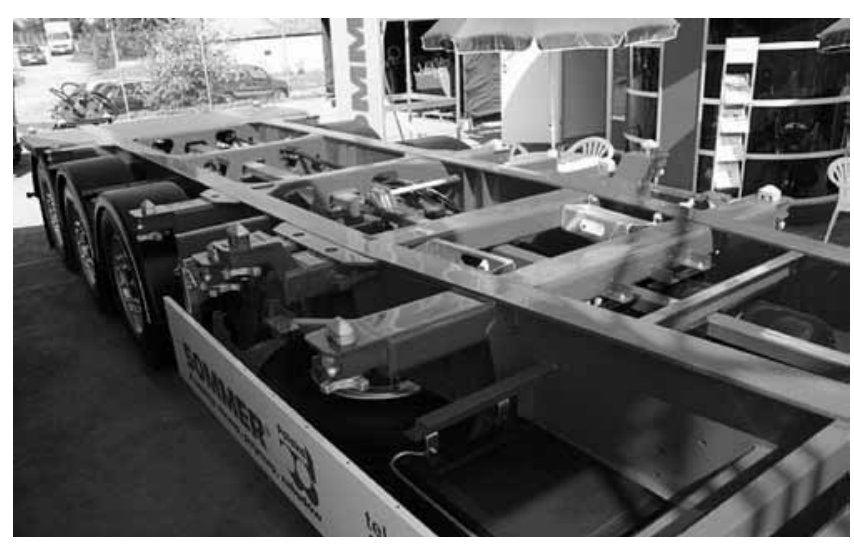

Rys. 2. Rama nośna naczepy ciężarowej marki Sommer [7]

Fig. 2. Frame bearer of a semitrailer truck Sommer [7] 
Każda z wyprodukowanych naczep musi spełniać określone wymagania. Jednym z podstawowych jest jej przeznaczenie. Naczepa może służyć do transportu kruszyw, płynów, drewna, zwierząt, artykułów spożywczych czy chociażby kontenerów.
Aby dopasować pojazd pod konkretne przeznaczenie, rama powinna mieć właściwe wymiary. Przykładowy produkt przeznaczony do transportu kontenerów morskich przedstawiono i zwymiarowano na rysunku 3.
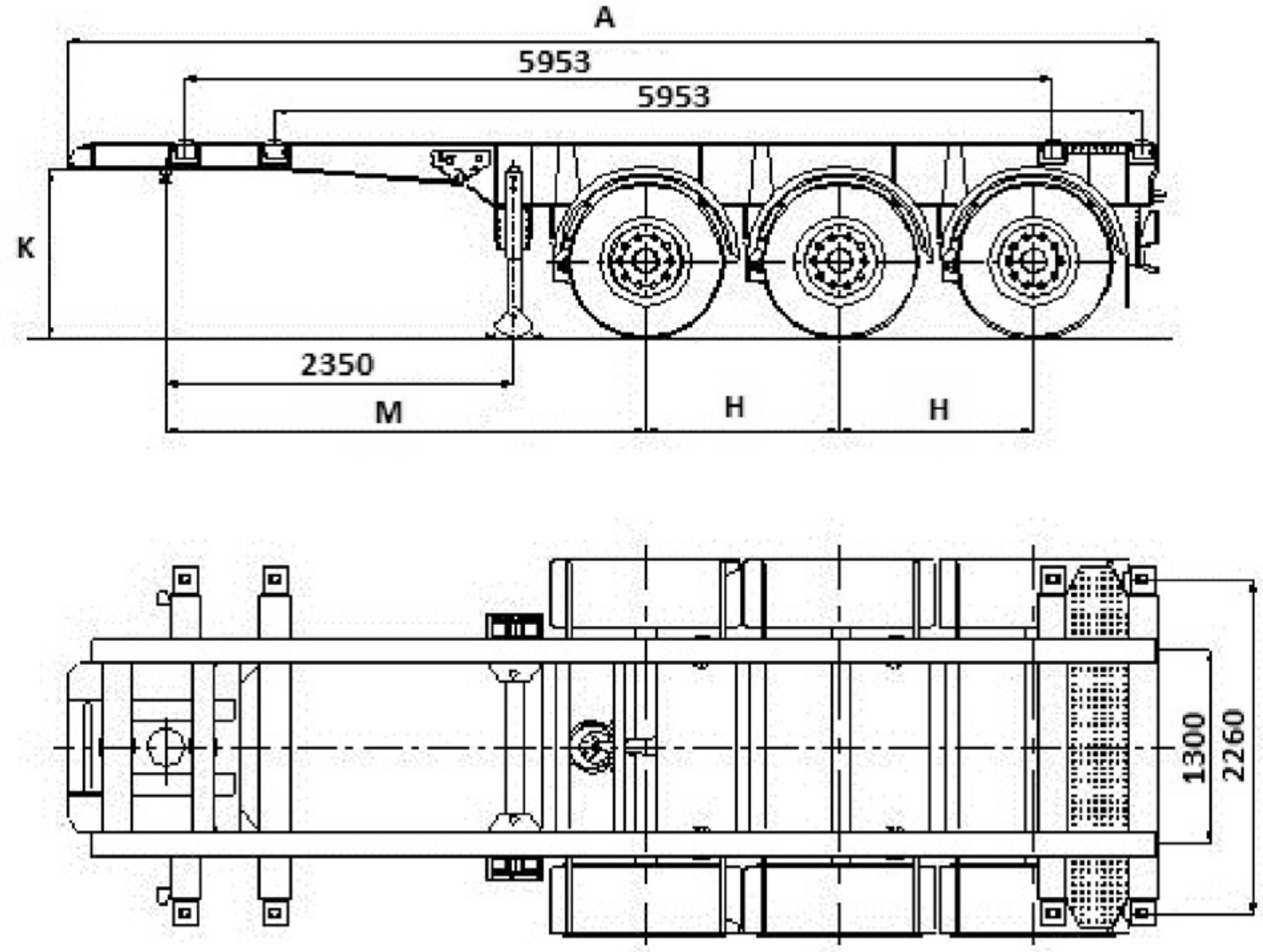

\begin{tabular}{|c|l|c|c|}
\hline \multicolumn{2}{|c|}{ Oznaczenie handlowe } & NS34 \\
\hline \multicolumn{2}{|c|}{ NS34PT /20/ NS34PB /20/ } \\
\hline A & Długość zewnętrzna & $\mathrm{mm}$ & 7400 \\
\hline C & Szerokość zewnętrzna & $\mathrm{mm}$ & 2540 \\
\hline $\mathrm{G}$ & Rozstaw kół & $\mathrm{mm}$ & 2 040/2 100 \\
\hline $\mathrm{H}$ & Rozstaw osi & $\mathrm{mm}$ & 1310 \\
\hline $\mathrm{K}$ & Wysokość siodła & $\mathrm{mm}$ & 1150 \\
\hline I & Wysokość platformy & $\mathrm{mm}$ & 1380 \\
\hline M & Rozstaw: czop - 1 oś & $\mathrm{mm}$ & 3240 \\
\hline Ogumienie & & $385 / 65$ R22.5 \\
\hline Dopuszczalna masa całkowita & $\mathrm{kg}$ & 36000 \\
\hline Masa własna & $\mathrm{kg}$ & 4050 \\
\hline Nacisk na oś & $\mathrm{kg}$ & $3 \times 8000$ \\
\hline Nacisk na siodło & $\mathrm{kg}$ & 12000 \\
\hline
\end{tabular}

Rys. 3. Rama naczepy Wielton NS34PT - wymiary

Fig. 3. Frame of a Wielton NS34PT semitrailer - dimensions 


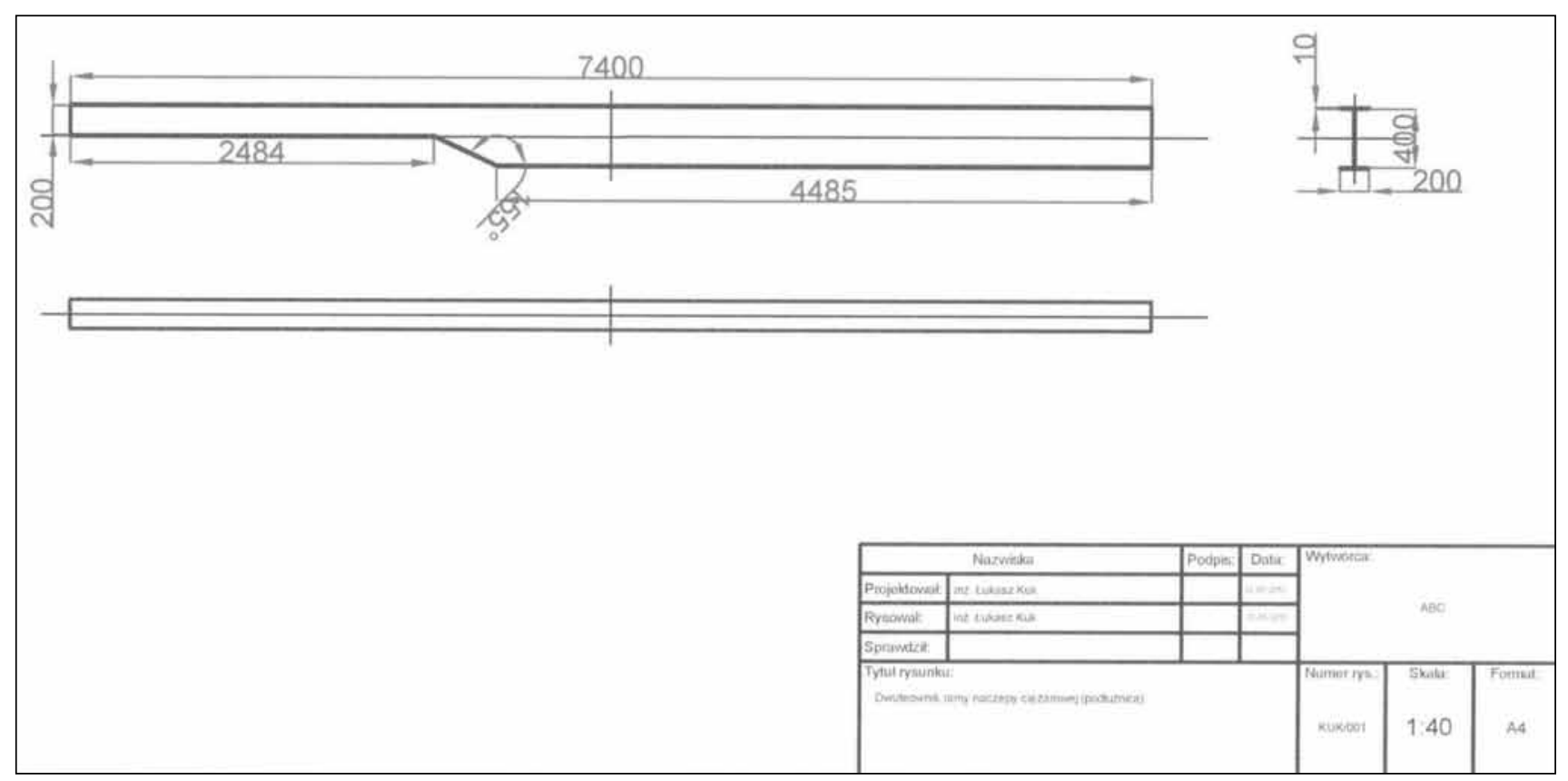

Rys. 4. Dwuteownik ramy naczepy ciężarowej

Fig. 4. An l-bar of a semitrailer truck frame

Rama naczepy składa się z dwóch podłużnic połączonych belkami poprzecznymi. Zwykle podłużnicę tworzy dwuteownik zespawany z płaskowników o określonych wymiarach. Kształt i wymiary dwuteownika przedstawiono na rysunku 4.

\section{Technologia spawania ram pojazdowych}

Łączenie ram w warunkach przemysłowych odbywa się w sposób zautomatyzowany. Można do tego celu wykorzystać przykładowo automat spawalniczy firmy ZAKMET model ASB 16000. Urządzenie przedstawiono na rysunku 5 .

Urządzenie ASB 16000 ma możliwość spawania belek nośnych naczep samochodów ciężarowych metodą MAG. Automat jest przystosowany do spawania ram o przekroju stałym, jak również o przekroju zmiennym. Umożliwia spawanie jednocześnie

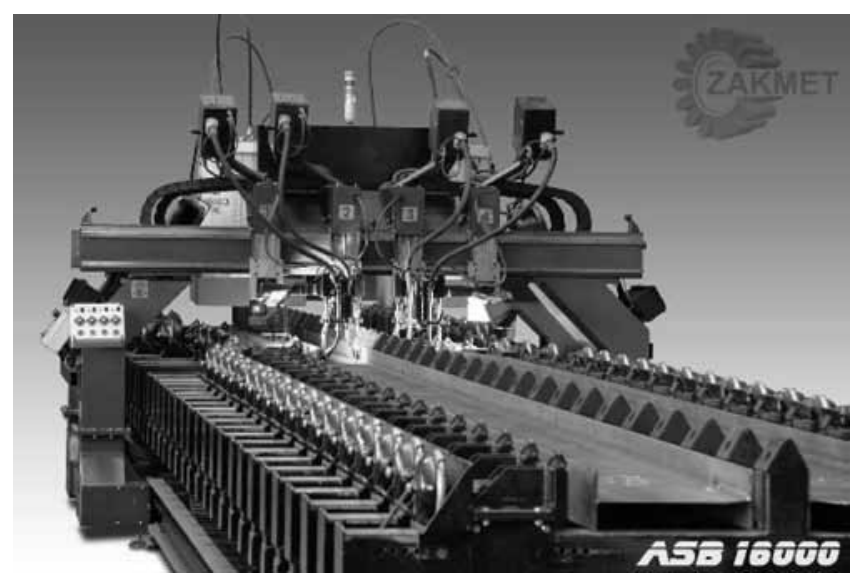

Rys. 5. Automat spawalniczy ASB 16000 [4]

Fig. 5. An automatic welder ASB 16000 [4] dwóch belek o długości do $16 \mathrm{~m}$. Spawanie może być prowadzone jednocześnie czterema palnikami, jak na rysunku 6. Dzięki temu naprężenia i odkształcenia w spawanych elementach są znacznie redukowane.

Każdy uchwyt spawalniczy jest indywidualnie sterowany w osiach X i Y. Portale zawierają wyłączniki krańcowe, a palniki złącza antykolizyjne. Urządzenie ASB 16000 składa się z następujących elementów [5]:

- stołu z zaciskami mocującymi,

- torowiska jezdnego,

- bramy jezdnej,

- 4 portali palników zamocowanych na bramie jezdnej,

- szafy sterowniczej,

- magazynu na 4 szt. rolek drutu po $250 \mathrm{~kg}$.

Podłużnice w postaci dwuteowników umieszcza się na stole roboczym.

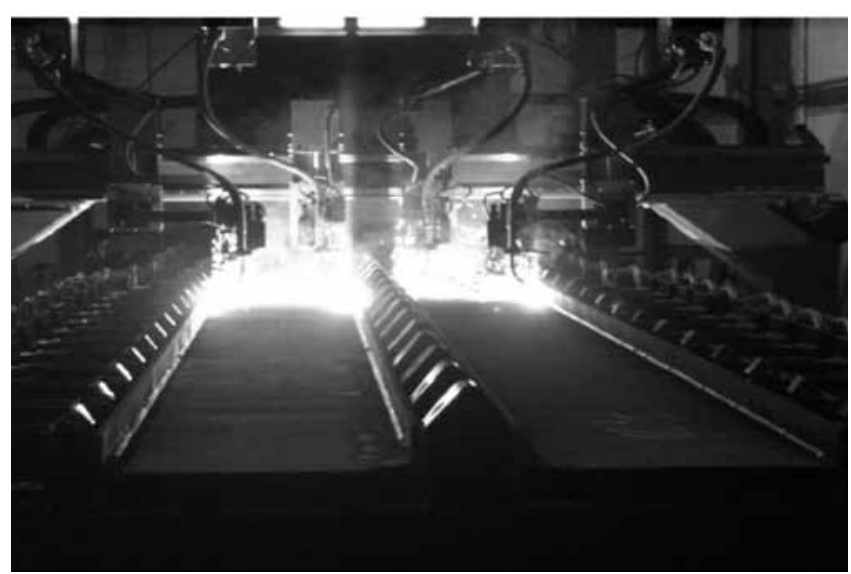

Rys. 6. Spawanie automatem ZAKMET z jednoczesnym wykorzystaniem 4 uchwytów spawalniczych [5].

Fig. 6. Welding by an automatic machine ZAKMET with a usage of 4 welding clamps [5] 
Ze względu na masę oraz gabaryty ram stosuje się transport wewnątrzzakładowy z wykorzystaniem suwnicy jak na rysunku 7.

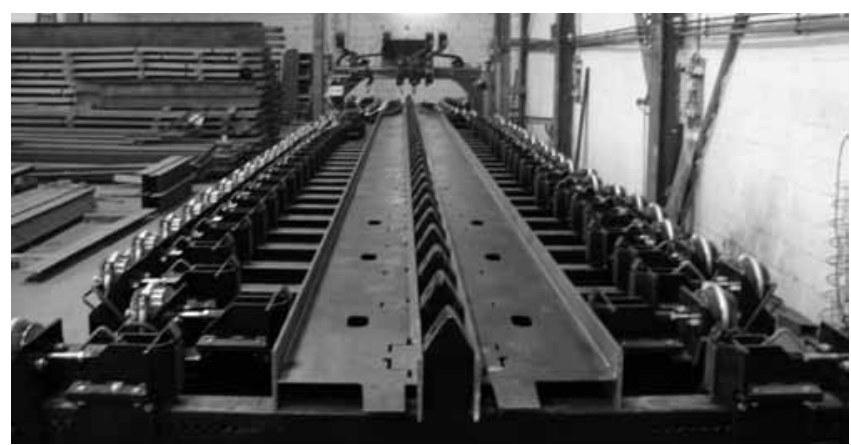

Rys. 7. Podłużnice ramy na stole roboczym automatu spawalniczego [6] Fig. 7. Frame side members on the working table of a welding automatic machine [6]

Spoiny wykonuje się metodą MAG z powodu:

- wyższej wydajności w porównaniu ze spawaniem elektrodą otuloną; nie występują wtedy przerwy na wymianę elektrody, większy jest też stopień wykorzystania drutu spawalniczego - brak wyrzucanych ogarków elektrod,

- uniwersalności metody - pozwala szybko uzyskać stopiwo bez względu na pozycję spawania,

- przydatności do spawania cienkich i średnich elementów stalowych, a także stopów aluminium.

W procesie spawania automatem ASB 16000 istotne jest również sterowanie. Do obsługi urządzenia wystarczy jeden operator, który za pomocą pulpitu steruje bramą jezdną, jak na rysunku 8.

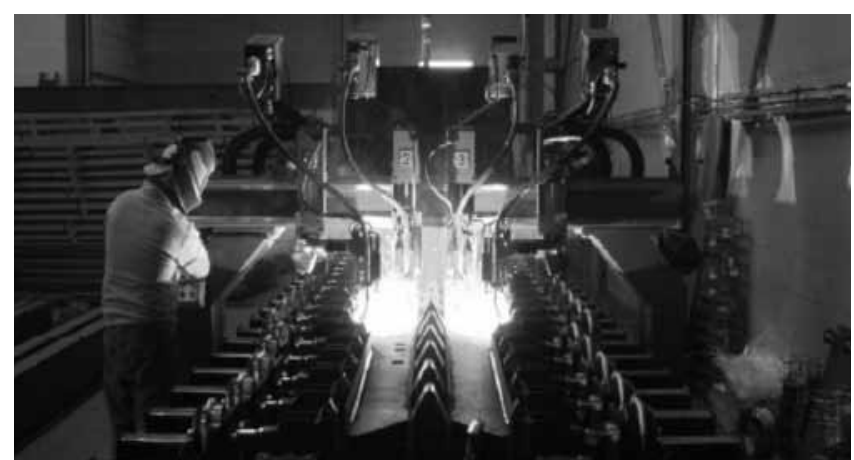

Rys. 8. Sterowanie bramą jezdną przez operatora [5]

Fig. 8. Operating of a running gate by a machine operator [5]

Układ sterowania składa się z czterech bloków funkcjonalnych, którymi są [5]:

- mikroprocesorowy blok prowadzenia i utrzymywania zadanej pozycji palników oraz śledzenia wykonanej spoiny,

- mikroprocesorowy blok sterowania bramą jezdną (prędkości przejazdowe, prędkości spawania, przejazd sczepiający podłużnicę),

- mikroprocesorowy układ PLC AMK5 z wizualizacją stanu wejść i wyjść, sterujący całością automatu,

- blok wyłączenia awaryjnego, obsługujący przyciski: awaria, wyłączniki krańcowe, złącza antykolizyjne palników, bariery zabezpieczające interfejs do sterowania źródłem prądu i podajnikiem drutu.
Pulpit sterowniczy umieszczony jest z lewej strony bramy jezdnej, tak aby dostęp do niego był łatwy, szybki i nie zagrażał bezpieczeństwu osoby obsługującej. Pulpit zaprezentowano na rysunku 9.

Otrzymane w ten sposób spoiny cechują się wysoką jakością oraz powtarzalnością. W warunkach przemysłowych to bardzo istotne, gdyż seryjna produkcja wymaga, aby wyroby były jednakowe pod każdym względem. Zastosowanie tradycyjnych metod, np. spawania ręcznego, nie zapewnia podobnego efektu. Jednakże można je stosować w pracach naprawczych.

$\mathrm{Na}$ rysunkach 10 i 11 zaprezentowano spoinę w przybliżeniu. Na rysunku 10 widać spoinę na surowym materiale, a na rysunku 11 na pojeździe przeznaczonym do odbioru przez klienta.

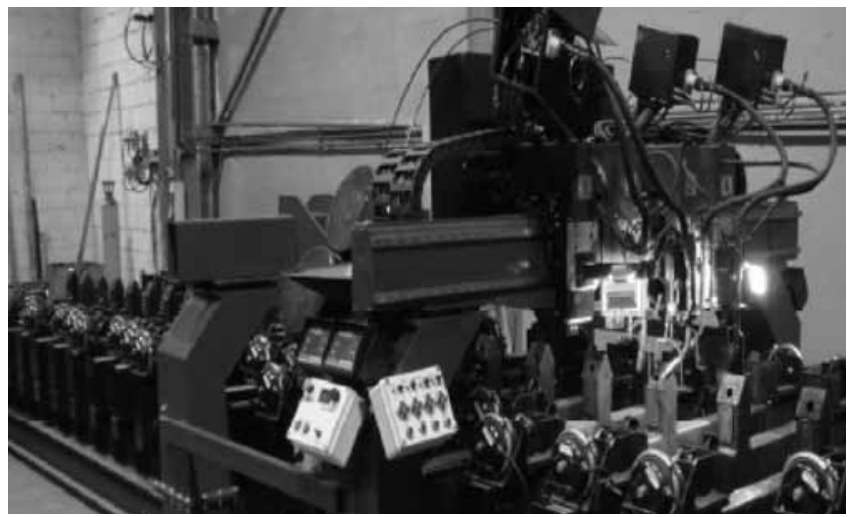

Rys. 9. Pulpit sterowniczy urządzenia ASB 16000

Fig. 9. An operating pulpit of ASB 16000 machine

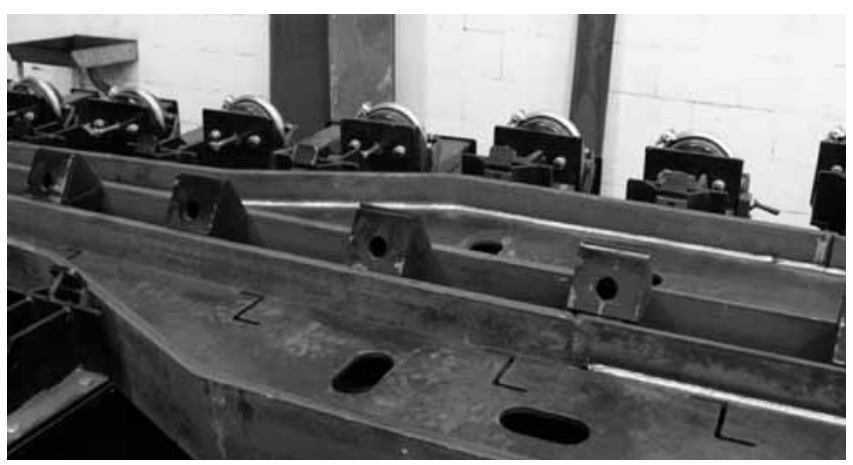

Rys. 10. Spoina na surowym materiale [6]

Fig. 10. A weld on a raw material [6]

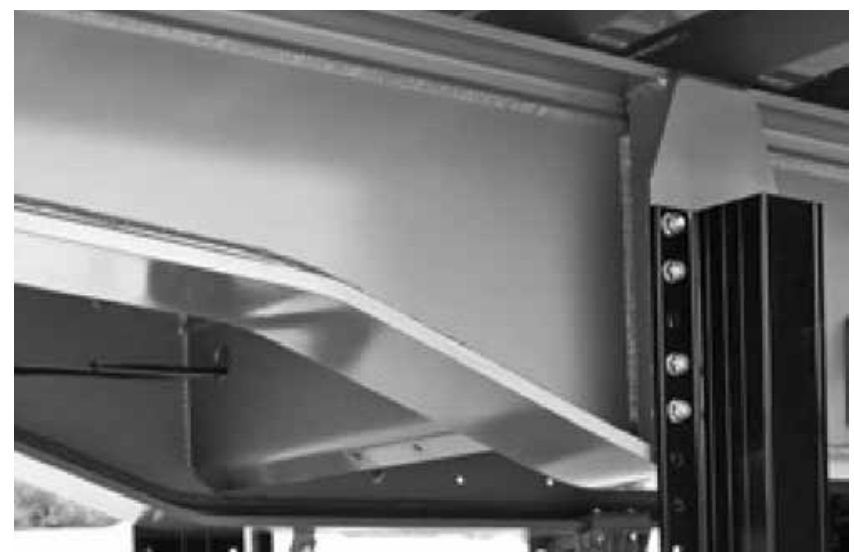

Rys. 11. Spoina gotowa do odbioru

Fig. 11. A view of a weld on a completed vehicle 
Do przedstawionej technologii opracowano instrukcję spawania (WPS).

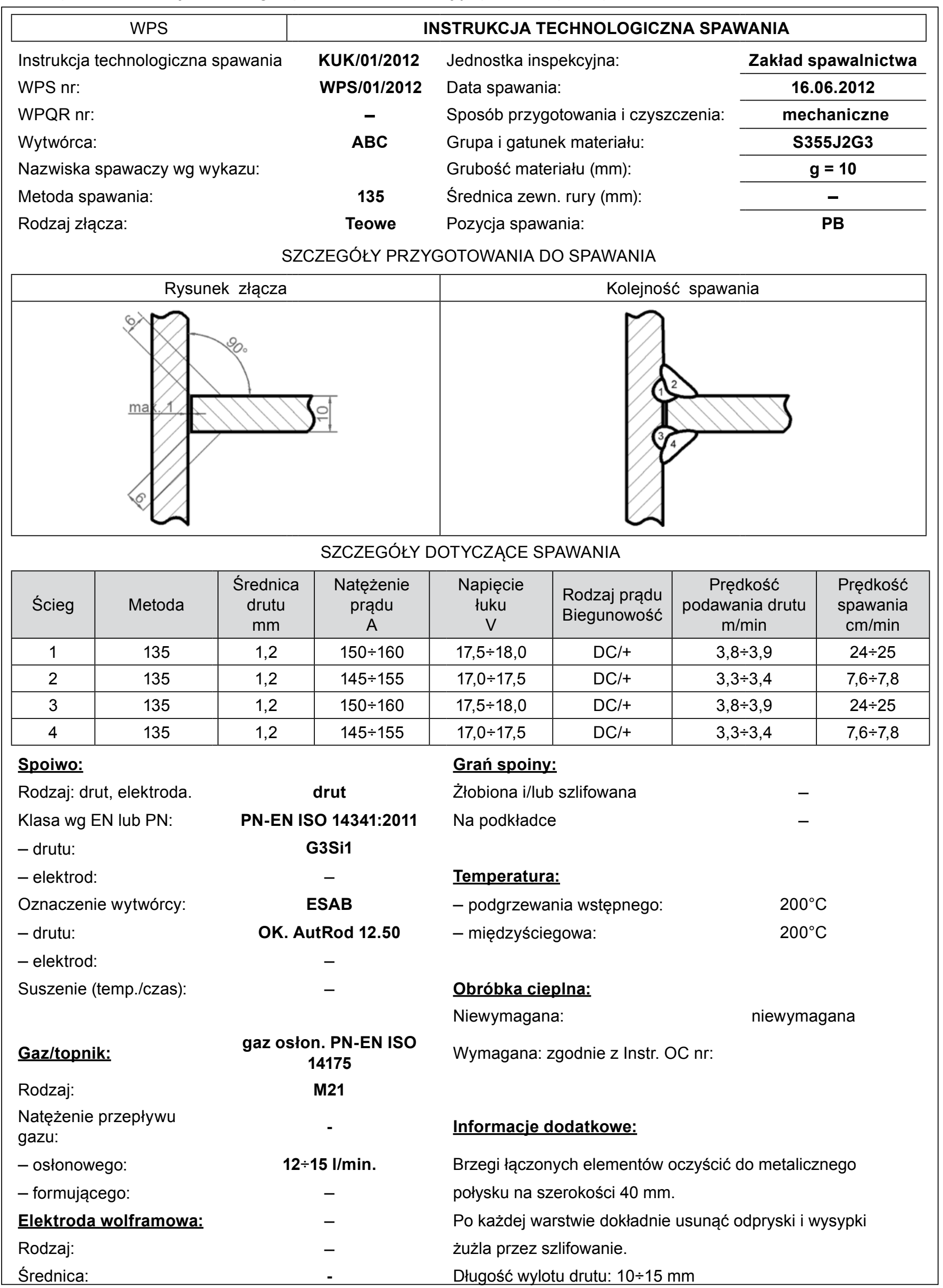




\section{Wnioski}

Dobór metody spawania ma wpływ na wytrzymałość i bezpieczeństwo konstrukcji spawanych ram samochodowych. Użycie metod spawalniczych niskotlenowych do łączenia elementów ram samochodowych pozwala uzyskać stopiwo o wyższej wytrzymałości na rozciąganie, wyższej granicy plastyczności oraz większej wytrzymałości zmęczeniowej. Ponadto stosowanie spawalniczej metody niskotlenowej w pracach naprawczych przekłada się na bezpieczną eksploatację pojazdu.

\section{Literatura}

[1] Węgrzyn T., Miros M.: Wytrzymałość złączy spawanych w ramach samochodów ciężarowych. Przegląd Spawalnictwa 2010, nr 3.

[2] Złoty P.: Transport. Technika Motoryzacyjna. Polskie czasopismo dla transportu i warsztatów. 2007, nr 5, s. $20 \div 25$.

[3] Praca zbiorowa, Poradnik Inżyniera. Spawalnictwo. T. 2. Warszawa, WNT 2005

[4] Strona internetowa: http://www.zakmet.de/?target=nowo\%B6ci. Dostęp: 16.05.2012.

[5] Strona internetowa: http://www.zakmet.de/source/ asb16000.pdf. Dostęp: 16.05.2012.

[6] Strona internetowa: http://www.amk.com.pl/?Produkty:Automatyzacja_spawania:Spawanie_naczep. Dostęp: 16.05.2012.

[7] Strona internetowa: http://www.kontenery.weldon.pl/pytania-i-odpowiedzi/. Dostęp: 16.05.2012.

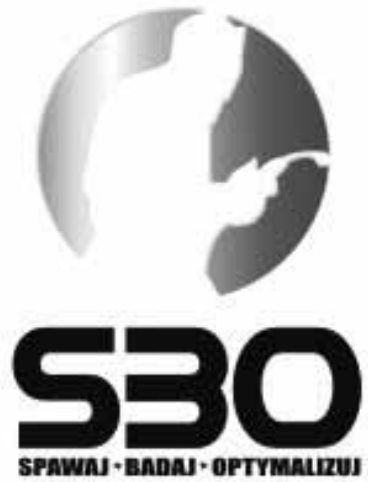

\section{Krajowa Konferencja Nowych Rozwiązań dla Motoryzacji}

Krajowa Konferencja Nowych Rozwiązań dla Motoryzacji to pierwsze spotkanie rozpoczynające cykl zjazdów organizowanych przez Śląskie Centrum Szkoleniowe, których tematem będą trzy najbardziej newralgiczne zakresy tematyczne związane z branżą motoryzacyjną, tj. Spawanie, Badania oraz Optymalizacja.

Tegoroczna konferencja zaplanowana została w terminie 29-30 maja 2014 r. w Centrum Konferencyjnym Rysy Nosalowy Dwór w Zakopanym. Merytoryczne aspekty sesji plenarnych przygotowywane są przez Komitet Naukowy wybitnych praktyków wielu uczelni wyższych naszego kraju. Grono Partnerów konferencji stanowią, zarówno doradcy działający na rynku polskim, jak i światowi producenci marek pojazdów.

Wszyscy uczestnicy konferencji, oprócz udziału w prelekcjach, będa mieli możliwość uczestnictwa w warsztatach, a także sesjach plakatowych. Zainteresowanych współtworzeniem naszych spotkań zapraszamy do kontaktu: (32) 7605928 oraz do odwiedzenia naszej strony internetowej: www.scs-szkolenia.pl, na której znajdą Państwo więcej informacji nt. konferencji. 